\title{
酛 New Disease Reports \\ First report of Tobacco mild green mosaic virus infecting tomato in Iran
}

\author{
A. Alishiri, F. Rakhshandehroo* and H.R. Zamanizadeh
}

Department of Plant Pathology, College of Agriculture and Natural Resources, Science and Research Branch, Islamic Azad University, Tehran 14515-775, Iran

*E-mail: rakhshandehroo_fa@srbiau.ac.ir

Received: 14 Nov 2010. Published: 29 Jun 2011. Keywords: Tobamoviruses, RT-PCR

Iran is amongst the seven top producers of tomato (Solanum lycopersicum) in the world with an approximate production of 4,826,396 tonnes yearly (Faostat, 2009). A number of plant viruses have been previously identified from tomato fields in Iran including Beet curly top virus (BCTV), Tomato spotted wilt virus (TSWV), Tobacco mosaic virus (TMV), Potato virus $Y$ (PVY), Tomato mosaic virus (ToMV) and Tomato yellow leaf curl virus (TYLCV) (Massumi et al., 2009). However, Tobacco mild green mosaic virus (TMGMV), already reported in pepper in Asia (Choi et al, 2002; Li \& Chang, 2005) has not been identified in Iran yet. Tobacco plants naturally infected with TMGMV show bright yellow to mild green mosaic or oak leaf patterns symptoms. In addition, most cultivars of pepper develop severe mosaic and necrosis symptoms followed by leaf drop in response to TMGMV (Wetter, 1989).

During August 2009 to July 2010, symptoms of interveinal chlorosis, and malformations and necrosis of leaves and stem, were observed in commercial tomato fields in the Karaj district of Tehran, Iran (Fig.1). Affected plants dried up at the final stage of the disease. Symptoms resembled those associated with TMGMV, which suggested this as the possible cause of the disease in tomato. Sap inoculation in tobacco plants (Nicotiana tabacum cv. Samsun) from symptom-bearing leaves of tomato plants resulted in the development of systemic mosaic and top necrosis in young leaves (Fig. 2). Total RNA was extracted from symptomatic leaf tissues and analysed by reverse transcription-polymerase chain reaction with TMGMV coat protein (cp) specific primers (Letscher et al., 2002) The 750-bp TMGMV-specific PCR fragment was amplified from six tomato samples collected from three fields in Karaj district and from all the post-inoculated tobacco plants. No amplification was observed from healthy samples of tomato or non-inoculated tobacco leaves. The TMGMV amplicon was purified $\left(\right.$ GeneJET $^{\mathrm{TM}}$ Gel Extraction Kit, Fermentas, Germany)and directly sequenced. The resultant partial cp gene sequence was deposited in GenBank (Accession No. HQ593622). BLAST of the TMGMV sequence analysis showed $91-100 \%$ identity at the amino acid level, and 72-80\% identity at the nucleotide level, with those of TMGMV isolates in GenBank (EF469769.1, M34077.1, AJ429096.1, AF103782.1). TMGMV can be long distance-transmitted by the infected seeds, so special recommendations should be followed as part of the disease management strategy. To our knowledge, this is the first report of TMGMV in Iran.

\section{References}

Choi G-S, Kim J-H, Ryu KH, Choi JK, Chae S-Y, Kim J-S, Chung B-N, Choi Y-M, 2002. First report of Tobacco mild green mosaic virus infecting pepper in Korea. The Plant Pathology Journal 18, 323-327.

Faostat, 2009. FAOSTAT. Preliminary 2009 production data. [http://faostat.fao.org/site/339/default.aspx]

Letscher B, Adam G, Lesemann D-E, Willingmann P, Heinze P, 2002. Detection and differentiation of serologically cross-reacting tobamoviruses of economical importance by RT-PCR and RT-PCR-RFLP. Journal of VirologicalMethods , 1-10. [doi:10.1016/S0166-0934(02)00135-0]

Li C-Y, Chang Y-C, 2005. First identification of Tobacco mild green mosaic virus on Capsicum annuum in Taiwan. Plant Pathology 54, 258 [doi:10.1111/i.1365-3059.2005.01171.x]

Massumi H, Shaabanian M, Hosseini Pour A, Heydarnejad J, Rahimian H, 2009. Incidence of viruses infecting tomato and their natural hosts in the southeast and central regions of Iran. Plant Disease 93, 67-72. [doi:10.1094/PDIS-93-1-0067]

Wetter C, 1989. Tobacco mild green mosaic virus. CMI/AAB Descriptions of Plant Viruses, No. 351. Kew, Surrey, UK: Commonwealth Mycological Institute.

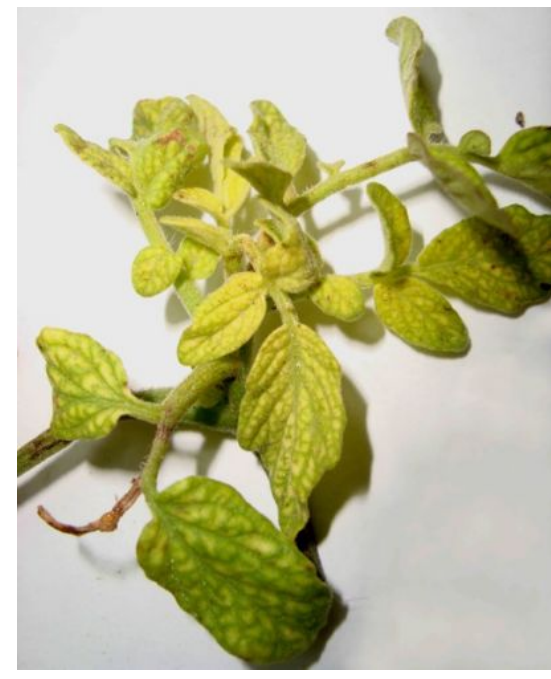

Figure 1

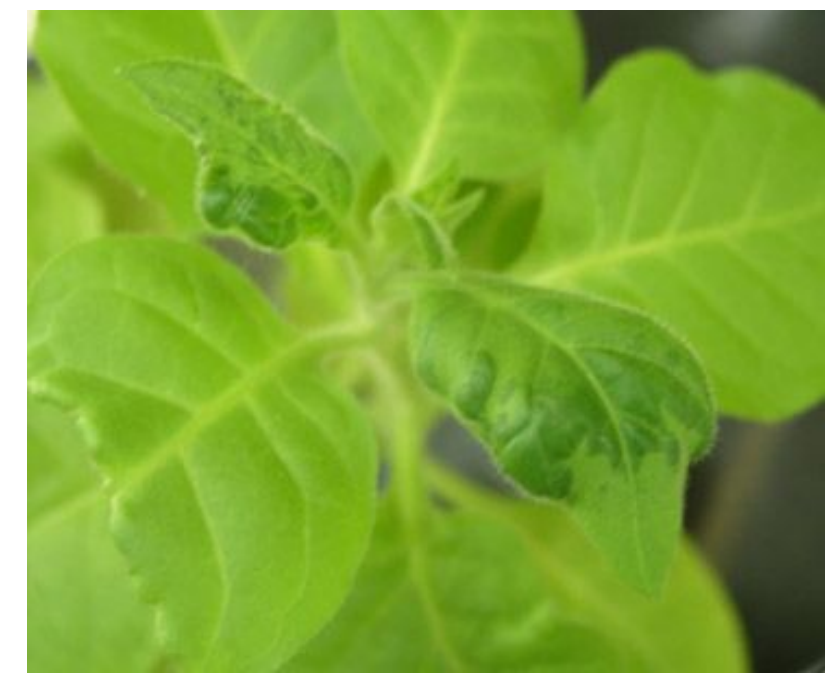

Figure 2

To cite this report: Alishiri A, Rakhshandehroo F, Zamanizadeh HR, 2011. First report of Tobacco mild green mosaic virus infecting tomato in Iran. New Disease Reports 23, 30. [doi:10.5197/j.2044-0588.2011.023.030]

C) 2011 The Authors

This report was published on-line at www.ndrs.org.uk where high quality versions of the figures can be found. 